\title{
Проблема патриотизма в современном российском обществе
}

\section{P. Б. Загыртдинов}

Уфимский государственный нефтяной технический университет, филиал в г. Стерлитамаке, Республика Башкортостан

zagyrtdinov@inbox.ru

Рассматриваются теоретические и практические аспекты проблемы патриотизма в современном российском обществе. Анализируются различные подходы к изучению патриотизма. Обосновывается актуальность его исследования на постсоветском пространстве в интересах консолидации общества, повышения уровня национальной безопасности в условиях информационной войны. Констатируется повышенное внимание органов государственной власти к состоянию патриотического сознания россиян. Утверждается возможность выработки интегральной теории патриотизма.

Ключевые слова: патриотизм; российская национальная идентичность; историческое сознание; постсоветское пространство.

\section{Problem of Patriotism in Modern Russian Society}

\section{R. B. Zagirtdinov}

Ufa State Oil Technical University Branch in Sterlitamak, Bashkortostan, Russia

zagyrtdinov@inbox.ru

The author considers theoretical and practical aspects of the problem of patriotism in modern Russian society, analyzing various approaches to the study of patriotism. He substantiates the topicality of this study in post-Soviet territory to the benefit of society consolidation and national security level heightening under conditions of information war. The author did state increased focus of government bodies on Russians' patriotic conscience. He has affirmed the possibility to elaborate an integrated theory of patriotism.

Keywords: patriotism; Russian national identity; conventional wisdom; post-Soviet territory.

Социологические опросы последних лет свидетельствуют о возрастании массового интереса к патриотическим идеям в современном российском обществе [1, с.125].

Актуализация темы патриотизма в современном обществе определяется несколькими обстоятельствами. Прежде всего, необходимостью выявления сущностных особенностей патриотизма, в соответствии с современной социально-политической

\footnotetext{
(c) Загыртдинов Р. Б.
}

и духовной практикой, в контексте современного социально-философского дискурса, а также определения основных социальных и политических аспектов патриотизма. Органы государственной власти РФ рассматривают патриотизм как важнейшую ценность, как средство формирования общенациональной идентичности. Это находит подтверждение в том, что патриотизму отводится значительное место 
в официальных документах, таких как Государственная программа «Патриотическое воспитание граждан Российской Федерации на 2016-2020 годы» [2]. Роль патриотизма определяется и подчеркивается в Федеральном государственном образовательном стандарте основного общего образования, который содержит следующие требования: «...Воспитание российской гражданской идентичности: патриотизма, уважения к Отечеству, прошлому и настоящему многонационального народа России; осознание своей этнической принадлежности, знание истории, языка, культуры своего народа, своего края, основ культурного наследия народов России и человечества; усвоение гуманистических, демократических и традиционных ценностей многонационального российского общества; воспитание чувства ответственности и долга перед Родиной» [3, п. 9].

Далее, проблема патриотизма является особенно актуальной в условиях трансформации общества и конструирования общенациональной гражданской идентичности, характерных для государств, проходящих стадию реформирования и политической модернизации (в частности для тех, что ранее входили в состав СССР). Лидеры, политические и интеллектуальные элиты государств постсоветского пространства пытаются найти социокультурные символы, способные консолидировать их граждан.

На начальном этапе процесса модернизации и трансформации политической системы России многие исследователи-теоретики и еще больше политиков-практиков не в полной мере осознавали значимость сохранения патриотизма как национальной идеи и ценностного основания процесса политических реформ. Некоторые политики предполагали, что с избавлением от коммунистической идеологии и советской политической системы реальная социальная практика сформирует новые идеологические ценности и стандарты. Деидеологизация и ценностный релятивизм привели к кризису патриотизма в российском обществе.
Сегодня воспитание патриотизма и поддержание на должном уровне патриотического сознания представляется первоочередной задачей государства и соответствующих социальных институтов. Социальная значимость исследования патриотизма дополняется его теоретической актуальностью, поскольку в рамках социальной философии ведутся дискуссии о сущности патриотизма и нет его единой, интегральной теории. На наш взгляд, современная отечественная философская мысль не уделяет должного внимания состоянию патриотизма в сложившихся условиях очевидного противоречия между потребностью общества в патриотах и отсутствием целостного представления о том, как увеличить их количество. В связи с этим проблема патриотизма в российском обществе требует целенаправленного научного исследования.

Носителями патриотического сознания являются как отдельные личности, так и социальные группы, и общество в целом. Как элемент общественного сознания патриотизм выступает одним из проявлений субъект-объектных отношений. Рассмотрение патриотизма сквозь призму системы общественных отношений позволяет полнее раскрыть его содержание и структуру, более эффективно в сравнении с другими методами выстроить понятийный аппарат исследования патриотизма, который позволит выявить основные его характеристики, соответствующие современному социальному контексту. Патриотическое сознание мы полагаем необходимым условием сохранения Родины, Отечества как единого целого. Многие исследователи роли патриотизма в общественной системе отводят ему связующую функцию между индивидом и этим единым целым. Отмечается также диалектическая природа патриотизма, которая проявляется в диалектическом единстве его интеграционной и дезинтеграционной функций в социуме: способствуя объединению граждан, патриотизм одновременно выступает фактором размежевания «своих» и «чужих». С позиций патриотизма, принадлежность к единому целому является для 
индивида приоритетной. Особое место сторонники патриотизма отводят государству, полагая, что целенаправленное формирование патриотического сознания в обществе, a также создание благоприятных условий для его проявления должны взять на себя государственные институты в тесном сотрудничестве с общественными организациями.

Социально-философский подход к изучению патриотизма включает в себя аксиологическую составляющую, предполагающую, с одной стороны, рассмотрение тех или иных из его ценностных оснований в той или иной стране в определенный период ее истории. С другой стороны, сам патриотизм рассматривается как вневременная ценность. Так, В. И. Лутовинов формулирует свое определение с аксиологических позиций: «Патриотизм понимается как одна из значимых непреходящих ценностей, присущая всем сферам жизни общества и государства, которая является важнейшим духовным состоянием личности, характеризует высший уровень ее развития и проявляется в ее активно-деятельностной самореализации на благо Отечества. Патриотизм олицетворяет любовь к своему Отечеству, сопричастность с его историей, культурой, достижениями, притягательными и неотделимыми в силу своей неповторимости и незаменимости, составляющими духовно-нравственную основу личности, формирующими ее гражданскую позицию и потребность в достойном, самоотверженном, вплоть до самопожертвования, служении Родине» [4, с. 205].

Профессор О. И. Елхова, анализируя российскую национальную идентичность, выделяет в качестве угрожающих ее устойчивости ряд проблем, связанных с виртуализацией реальности. Автор отмечает, что у субъекта, захваченного виртуальной средой на уровне ежедневного существования, ослабевает способность осознавать свою принадлежность к реальному государству, что может привести к утрате жизненных ориентиров [5, с. 552].

Патриотизм служит личности своего рода инструментом защиты, блокировки, нейтрализации различных угроз, обеспечивающим ей невосприимчивость к внешним и внутренним воздействиям, которые постоянно испытывают ее на прочность.

Как известно, любые факторы, воздействующие на систему, могут влиять на нее положительно или отрицательно. Позитивные, конструктивные воздействия направлены на повышение стабильности, устойчивости системы, на сохранение и развитие ее сущностных параметров, деструктивные на разрушение стабильного существования системы, на деформацию ее сущностных параметров, на погружение ее в состояние хаоса. Угроза для общественной системы характеризуется как деструктивный, отрицательный фактор. Однако угрозы существовали всегда, они - атрибут любой системы, и нередко трудно однозначно квалифицировать воздействие на систему только как позитивное или негативное, т. е. выявить угрозу не всегда удается, пока она не начнет разрушительное действие.

Вместе с тем в современном мире происходит неуклонное смещение проблемы безопасности в концептуально-смысловую сферу. Во многом это обусловлено главной особенностью современной социальной жизни - ее необычайным динамизмом.

Действительно, характерный признак нашего времени - тотальная изменчивость, подвижность происходящего. Состояние человека, пребывающего в пространстве подвижного, изменчивого социального бытия, можно охарактеризовать как экзистенциальный кризис. Еще Конфуций справедливо предостерегал: «Не дай вам бог жить в эпоху перемен», тем самым давая вполне определенную упреждающую оценку тотального динамизма и последующего отношения человека к нему.

Термин «текучая современность» впервые употребил 3. Бауман, вынеся его в название своей работы [6], в которой сопоставляются две реальности: твердая, соответствующая индустриальной эпохе, и текучая, легкая, соответствующая эпохе постмодерн. В такой реальности нет строго 
фиксированного понимания событий, одной-единственной их интерпретации, равно как нет единственной истины.

В противовес текучей, устойчивая реальность характеризуется фундаментальным укоренением человека и результатов его деятельности в бытии. Однако в процессе перехода от индустриального к постиндустриальному обществу социальная реальность словно размягчается, расплавляется. Можно сказать, что текучая, легкая современность имеет онтологические, гносеологические, антропологические и психологические основания, которые тесно переплетены между собой и генерируют весьма причудливую картину реальной действительности.

Патриотизм в контексте меняющейся современности тоже претерпевает радикальную трансформацию, что требует поиска новых мировоззренческих и методологических подходов к проблеме его изучения.

Социально-философский подход дает возможность рассмотреть цивилизационно-региональные аспекты патриотизма.

В период существования СССР в рамках единой политической культуры и идеологии сохранялись и развивались национально-региональные социально-политические субкультуры.

На наш взгляд, органичной частью общероссийского патриотизма является башкирский (патриотизм многонационального народа Республики Башкортостан). Исторически сложилось так, что башкирский народ совместно с другими народами великой России выполнял важнейшие функции защиты ее рубежей. Особенно ярко это проявлялось в периоды войн. Так, в ходе Отечественной войны 1812 г. башкирская конница сыграла заметную роль в победе над Наполеоном [7; 8].

Патриотизм многонационального народа Башкортостана вдохновлял бойцов на подвиги и в годы Великой Отечественной войны. О героизме воинов 112-й кавалерийской дивизии написано много (см., напр., [9]) и, на наш взгляд, вполне заслуженно, учитывая количество Героев Советского
Союза в данном воинском подразделении. Объем и содержание публикаций дают основание говорить о сознательной официальной героизации солдат и офицеров легендарной дивизии.

К сожалению, в последнее время фальсификация истории становится инструментом реальной политики вероятных противников России. Сегодня ими уже разработаны и постоянно совершенствуются мощные технологии, дающие широкие возможности для трансформации образов российского прошлого и манипуляции историческим сознанием.

В содержательном плане они включают в себя активное внедрение искаженных образов в индивидуальное и общественное историческое сознание россиян, в их историческую память. Как известно, бытие человека складывается из осознания им своего прошлого, фиксации различия между прошлым и настоящим и формирования образа ожидаемого будущего. Таким образом, технологии фальсификации одновременно воздействуют на прошлое, настоящее и будущее. Российскому обществу жестко навязываются искаженные представления о прошлом, что неизбежно приводит к изменению представлений россиян о настоящем и как следствие - картины ожидаемого ими будущего. В обществе подрывается способность критически и рационально оценивать исторические события, целенаправленно формируется нерефлективная позиция индивидов в отношении к историческому прошлому. Вслед за «распадом связи времен» разрывается единое историческое пространство, нарушается преемственность прошлого - настоящего - будущего. Более того, провоцируются и поощряются различные «фобии», связанные с событиями исторического прошлого, в результате чего оно начинает вызывать ненависть, настоящее неприятие, а будущее - страх. Такие технологии способны значительно трансформировать духовную ситуацию в обществе, спровоцировать эмоциональные потрясения, вызвать ощутимый сдвиг в ценностной сфере: стереть границы между добром 
и злом, нравственным и безнравственным. В ситуации социокультурной аномии (терминология Э.Дюркгейма) человек под влиянием мощного экзистенциального потрясения легко становится объектом манипулирования, безмолвной жертвой сомнительных социальных экспериментов.

Отметим, что в современных условиях информационного общества и разворачивания глобализационных процессов большинство развитых и развивающихся стран мира озабочены вопросом поддержания и повышения уровня национальной безопасности. В последние десятилетия в России также разрабатываются доктрины национальной безопасности, что несомненно важно для сохранения целостности и самодостаточности страны. Воспитание патриотизма является одной из задач, поставленных в правительственных программах.

Таким образом, обращаясь к столь сложному и многогранному явлению, как патриотизм, сторонники рассмотренных теоретических подходов к его изучению анализируют отдельные аспекты этого феномена, что препятствует целостному видению проблемы. Более того, некоторые авторы настаивают на том, что всесторонне исследовать сущность патриотизма невозможно и все попытки сформулировать его единое, точное, универсальное определение изначально обречены на неудачу. Мы полагаем, что это не так. На наш взгляд, социально-философский анализ патриотизма позволяет рассматривать отдельные его аспекты как своеобразные элементы мозаики, из которых может быть выстроено целостное представление об исследуемом явлении.

\section{Лuтература}

1. Покида A. H. Специфика патриотических чувств россиян // Власть. 2010. № 12. С. 124-129.

2. Государственная программа «Патриотическое воспитание граждан Российской Федерации на 20162020 годы»: утв. постановлением Правительства РФ от 30.12.2015 № 1493 // Правительство России [электронный ресурс] / Правительство Российской Федерации. URL: http://government.ru/docs/all/105292/ (дата обращения: 06.06.2018).

3. Федеральный государственный образовательный стандарт основного общего образования: утв. приказом Министерства образования и науки
Российской Федерации от 17.12.2010 № 1897 // Российское образование: федеральный портал: [электронный ресурс] / ФГАУ ГНИИ ИТТ «ИнформиKa». URL: http://www.edu.ru/db-mon/mo/Data/d_10/ prm1897-1.pdf (дата обращения: 06.06.2018).

4. Лутовинов В. И. В патриотизме молодежи будущее России. М.: Фонд Андрея Первозванного, 1999. $206 \mathrm{c}$.

5. Елхова О. И. Сохранение российской национальной идентичности в информационном мире // Вестник Башкирского университета. 2017. Т. 22 № 2. C. $551-554$.

6. Бауман 3. Текучая современность / Пер. с англ. под ред. Ю. В. Асочакова. СПб.: Питер, 2008. 240 с.

7. Усманов А. Н. Башкирский народ в Отечественной войне (1812). Уфа: Китап, 2012. 140 с.

8. Вклад Башкирии в победу России в Отечественной войне 1812 года: 1812-2012: сб. документов и мат-лов. Уфа: Китап, 2012. 487 с.

9. Аюпов P. С. Вклад Башкирской АССР в разгром немецко-фашистских захватчиков в годы Великой Отечественной войны 1941-1945 гг. // Экономика и управление: научно-практический журнал. 2010. № 1. C. $46-52$.

Поступила 11.05.2018

\begin{abstract}
Загыртдинов Рафиль Борисович - старший преподаватель кафедры гуманитарных наук филиала Уфимского государственного нефтяного технического университета в г. Стерлитамаке (Россия, 453118, Республика Башкортостан, г. Стерлитамак, Проспект Октября, 2), zagyrtdinov@inbox.ru
\end{abstract}

\section{References}

1. Pokida A. N. Spetsifika patrioticheskikh chuvstv rossiyan (Peculiarity of Russians' Patriotic Feelings), Vlast', 2010, No. 12, pp. 124-129.

2. "Gosudarstvennaya programma 'Patrioticheskoe vospitanie grazhdan Rossiiskoi Federatsii na 2016-2020 gody', utv. postanovleniem Pravitel'stva RF ot 30.12.2015 No. 1493" (State-Run Program "Patriotic Education of Russian Federation Citizens for the Years 2016 to 2020", Approved by RF Government Regulation from 30 Dec. 2015 No. 1493). Pravitel'stvo Rossii. Pravitel'stvo Rossiiskoi Federatsii, n. d. Web. 6 June 2018. <http://government.ru/docs/all/105292/>.

3. "Federal'nyi gosudarstvennyi obrazovatel'nyi standart osnovnogo obshchego obrazovaniya, utv. prikazom Ministerstva obrazovaniya i nauki Rossiiskoi Federatsii ot 17.12.2010 No. 1897" (Federal State Educational Standard of Basic General Education, Approved by Order of the Ministry of Education and Science of the Russian Federation from 17 Dec. 2010 No. 1897). Rossiiskoe obrazovanie, federal'nyi portal. FGAU GNII ITT "Informika", n. d. Web. 6 June 2018. <http://www.edu.ru/db-mon/mo/ Data/d_10/prm1897-1.pdf $>$.

4. Lutovinov V. I. V patriotizme molodezhi - budushchee Rossii (Future of Russia is in Young People's Patriotism), M., Fond Andreya Pervozvannogo, 1999, 206 p. 
5. Elkhova O. I. Sokhranenie rossiiskoi natsional'noi identichnosti $\mathrm{v}$ informatsionnom mire (Protection of Russian National Identity in the Information World), Vestnik Bashkirskogo universiteta, 2017, T. 22 No. 2, pp. 551-554.

6. Bauman Z. Tekuchaya sovremennost' (Liquid Modernity), Per. s angl. pod red. Yu. V. Asochakova, SPb., Piter, 2008, 240 p.

7. Usmanov A. N. Bashkirskii narod v Otechestvennoi voine (1812) (Bashkir People in Patriotic War (1812)), Ufa, Kitap, 2012, 140 p.

8. Vklad Bashkirii v pobedu Rossii v Otechestvennoi voine 1812 goda: 1812-2012 (Bashkiria's Contribution to the Victory of Russia in Patriotic War of 1812: 1812 to 2012), sb. dokumentov i mat-lov, Ufa, Kitap, 2012, 487 p.
9. Ayupov R. S. Vklad Bashkirskoi ASSR v razgrom nemetsko-fashistskikh zakhvatchikov v gody Velikoi Otechestvennoi voiny 1941-1945 gg. (Contribution of Bashkir Autonomous Soviet Socialist Republic to German Nazi Invaders' Defeat in the Years of Great Patriotic War, 1941 to 1945), Ekonomika i upravlenie: nauchno-prakticheskii zhurnal, 2010, No. 1, pp. 46-52.

Submitted 11.05.2018

Zagirtdinov Rafil B., senior lecturer of Humanities Department, Ufa State Oil Technical University Branch in Sterlitamak (Russia, 453118, Bashkortostan, Sterlitamak, October ave., 2), zagyrtdinov@inbox.ru 